\title{
Study on the Enantioselective Degradation of Imazethapyr in Soil by CE
}

\author{
Li Han ${ }^{1,2}$, Baoyuan Guo ${ }^{1, 凶}$, Junhe Feng ${ }^{1,2}$, Xiaoming Lu², Jin-Ming Lin ${ }^{1,3, 凶}$ \\ 1 State Key Laboratory of Environmental Chemistry and Ecotoxicology, Research Center for Eco-Environmental Sciences, \\ Chinese Academy Sciences, P.O. Box 2871, 100085 Beijing, China; E-Mail: guoby@rcees.ac.cn \\ 2 Department of Chemistry, Capital Normal University, 100037 Beijing, China \\ ${ }^{3}$ The Key Laboratory of Bioorganic Phosphorus Chemistry and Chemical Biology, Department of Chemistry, Tsinghua University, \\ 100084 Beijing, China; E-Mail: jmlin@mail.tsinghua.edu.cn
}

\begin{abstract}
A method was developed for the separation of imazethapyr enantiomers using capillary electrophoresis and large volume injection. Optimized buffer conditions were found using 6\% hydroxypropyl- $\beta$-cyclodextrin as the chiral selector at $\mathrm{pH} 11$ with an injection time of $20 \mathrm{~s}$ (0.5 psi). The limits of detection (LOD, $S / N=3$ ) were 0.22 and $0.23 \mathrm{mg} \mathrm{L}^{-1}$ for the two imazethapyr enantiomers (imazethapyr-I and imazethapyr-II) respectively. The relative standard deviation was less than $5 \%$. This method was successfully used in the study of enantioselective degradation of this herbicide in field soil and the results suggested that imazethapyr-I degraded at a higher rate when compared with imazethapyr-II.
\end{abstract}

\section{Keywords}

Capillary zone electrophoresis

Enantioselective degradation

Emazethapyr

Soil

\section{Introduction}

Many pesticides are chiral compounds and consist of two or more enantiomers, which may differ in biological activity, toxicity, and environmental fate [1]. Several racemic pesticides have been replaced by one isomer in the attempt to decrease the release of inactive isomers into the biosphere. In recent years, enantioselective degradation of various herbicides in soil have been described [2].

Imidazolinone herbicides are chiral compounds and widely used for broadspectrum weed control and previous studies reported on enantioselective herbicidal activity [3, 4]. Ramezani and colleagues studied the photodegradation of imazaquin and found that no enantioselective degradation has been observed in water [4]. Imazethapyr shows excellent activity against annual and perennial grass and broadleaved weeds [5].

Capillary electrophoresis (CE) is an important, rapid and versatile technique for the separation and determination of chiral herbicides [3]. A wide range of chiral selectors are added to the running buffer in order to achieve chiral separation. Commonly used additives include cyclodextrins (CDs), macrocyclic glycopeptide antibiotics, crown ethers and proteins [6]. In the present study, a CD derivative was selected for the analysis of enantioselective degradation of imazethapyr in field soil.

\section{Materials and Methods}

\section{Chemicals}

All the reagents, except imazethapyr, were of analytical grade. Imazethapyr (98\%) was purchased from Jingmei Chemical Industry Company (Hebei, China). Hydroxypropyl- $\beta$-cyclodextrin 
Table 1. Characteristics of the proposed CE method under optimized conditions

\begin{tabular}{|c|c|c|c|c|c|c|c|c|c|}
\hline & $a$ & $b$ & $r^{-2}$ & $\begin{array}{l}\text { Linear Range } \\
\left(\mathrm{mg} \mathrm{L}^{-1}\right)\end{array}$ & $\begin{array}{l}\mathrm{LOD} \\
\left(\mathrm{mg} \mathrm{L}^{-1}\right)\end{array}$ & $\begin{array}{l}\mathrm{LOQ} \\
\left(\mathrm{mg} \mathrm{L}^{-1}\right)\end{array}$ & $\begin{array}{l}\text { RSD } \\
(\%)(n=6)\end{array}$ & $\begin{array}{l}\text { Recovery } \\
(\%)(15 \mathrm{mg} \\
\left.\mathrm{kg}^{-1} \text { soil }\right)\end{array}$ & $\begin{array}{l}\text { Recovery (\%) } \\
\left(5 \mathrm{mg} \mathrm{kg}^{-1} \text { soil) }\right.\end{array}$ \\
\hline Imazethapyr-I & 852.64 & 711.59 & 0.999 & $0.49-14.77$ & 0.22 & 0.56 & 2.39 & 87.81 & 83.61 \\
\hline Imazethapyr-II & 835.52 & 751.20 & 0.999 & $0.51-15.23$ & 0.23 & 0.58 & 2.54 & 88.32 & 83.75 \\
\hline
\end{tabular}

Calibration curves are expressed as regression lines $(y=a x+b)$, where $y$ is the ratio of the peak area of enantiomeric compound, $x$ is enantiomer concentration ( $\left.\mathrm{mg} \mathrm{L}^{-1}\right), a$ is slope, $b$ is intercept, and $r^{2}$ is the correlation coefficient
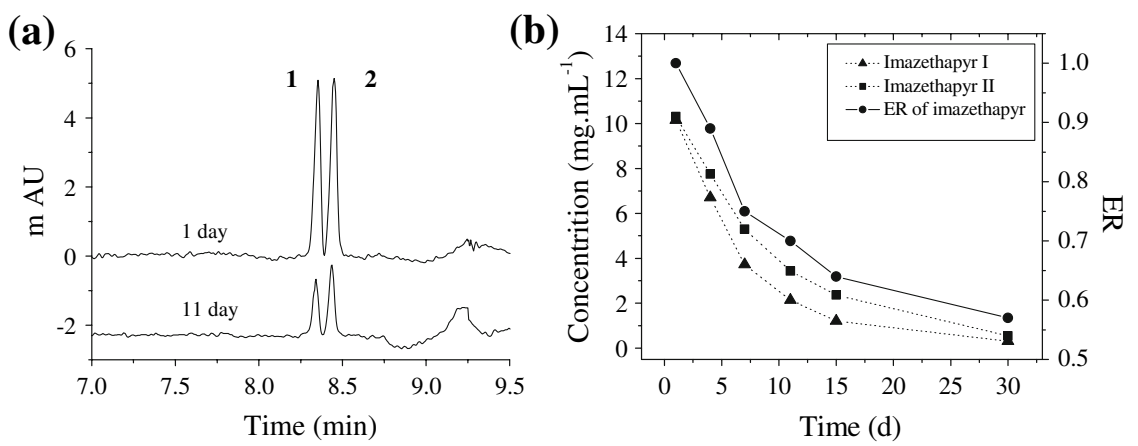

Fig. 1. Degradation of imazethapyr in field experiments. a Capillary electropherograms of imazethapyr degradation after day 1 and 11, respectively. For experimental conditions see "Experimental". b Degradation of imazethapyr over the period of 30 days showing decreased concentration and ER values. Peaks: $\mathbf{1}=$ imazethapyr-I, $\mathbf{2}=$ imazethapyr-II

(HP- $\beta$-CD) was purchased from Acros Organics (Fair Lawn, NJ, USA).

\section{Apparatus and CE Separation Condition}

CE separation was carried out on a Beckmann P/ACE MDQ CE system with a UV detector at $214 \mathrm{~nm}$ (Beckman, Fullerton, CA, USA). A fused silica capillary (Yongnian, Hebei, China), $50 \mu \mathrm{m}$ i.d., total length of $60 \mathrm{~cm}(50 \mathrm{~cm}$ to detector), was used. Before first use, the capillary was flushed with $1 \mathrm{M}$ $\mathrm{NaOH}$ for $10 \mathrm{~min}$, ultrapure water for $10 \mathrm{~min}$, and finally with the running buffer for $10 \mathrm{~min}$. Between runs the capillary was flushed with ultrapure water for $3 \mathrm{~min}$. The running buffer was a $25 \mathrm{mM}$ phosphate solution containing $6 \% \mathrm{HP}-\beta$-CD ( $\mathrm{pH} 11)$. Injection samples were prepared by diluting the stock solution of imazethapyr (1000 mg L $^{-1}$ in methanol) with water containing $6 \%$ HP- $\beta$-CD. Pressure injections were performed at 0.5 psi and injection time was $20 \mathrm{~s}$. Separation voltage was $20 \mathrm{kV}$ and temperature was controlled at $25^{\circ} \mathrm{C}$.

\section{Sample Treatment}

The soil samples were collected from a Setaria faberi field located at Qinghe, Beijing. During the flourishing period, imazethapyr was sprayed thoroughly at $0.2 \mathrm{~g} \mathrm{~m}^{-2}$. Soil samples $(15 \mathrm{~g})$ were randomly collected at a depth of about $1-15 \mathrm{~cm}$ from the surface soil on days 0 , $1,4,7,11,15$ and 30 , respectively. The soil samples were sieved $(2 \mathrm{~mm})$ and mixed with $20 \mathrm{~mL}$ methanol and then ultrasonicated for $30 \mathrm{~min}$. After filtration the soil phase was extracted twice with fresh solvents. The filtrate was combined and concentrated on a rotary evaporator to near dryness. For analysis, the residue was filtered through a $0.45 \mu \mathrm{m}$ filter and dissolved in $2 \mathrm{~mL}$ ultrapure water containing $6 \% \mathrm{HP}-\beta$ CD.

\section{Results and Discussion}

\section{Method Development}

HP- $\beta$-CD is chemically modified with hydroxypropyl groups which results in good aqueous solubility and it was anticipated to achieve ideal separation of imazethapyr enantiomers.

The $\mathrm{pH}$ value is one of the most important factors for CE separations and considering that imazethapyr has three $\mathrm{p} K_{\mathrm{a}}$ values of $2.1,3.8$ and 10.5 , we studied the $\mathrm{pH}$ from 3 to 12 during separation. Two optimized $\mathrm{pH}$ values were observed at $\mathrm{pH} 6.5$ and 12, respectively. When the $\mathrm{pH}$ was above 4 , the imazethapyr enantiomers only partially separated. Increased $\mathrm{pH}$ values improved interactions between enantiomers and HP- $\beta-\mathrm{CD}$, resulting in improved separation with a maximum resolution at $\mathrm{pH}$ 6.5. From $\mathrm{pH} 6$ to $\mathrm{pH}$ 9 , the resolution of the enantiomers decreased, but it was subsequently observed to increase again from $\mathrm{pH} 9$ to $\mathrm{pH} 12$, which was probably based on the $\mathrm{p} K_{\mathrm{a}}$ of 10.5 and increased ionization. Ultimately, $\mathrm{pH} 11$ was chosen for the separation based on the fact that the observed current was considered too high at $\mathrm{pH} 12$.

The resolution was observed to be poor when sample matrix and buffer were identical. When the sample matrix did not contain any electrolytes, resolution was found to increase to 1.5. To enhance the detection, a $20 \mathrm{~s}$ injection time was selected.

\section{Method Validation}

For imazethapyr-I and imazethapyr-II, the limits of detection (LOD, $\mathrm{S} / \mathrm{N}=3$ ) were determined to be at 0.22 and $0.23 \mathrm{mg} \mathrm{L}^{-1}$ and the limits of quantification (LOQ, $\mathrm{S} / \mathrm{N}=3$ ) were 0.56 and $0.58 \mathrm{mg} \mathrm{L}^{-1}$, respectively (Table 1 ). Recoveries, RSD and calibration curves for both imazethapyr enantiomers are also shown. 


\section{Degradation of Imazethapyr in Soil}

The enantiometric ratio (ER) was defined according to literature [3] to evaluate the enantioselective degradation. Figure 1 shows that imazethapyr-I appeared to degrade faster than imazethapyr-II, and ER slowly decreased over time from 0.97 (day 1) to 0.58 (day 30), which indicated enantioselective degradation of both enantiomers.

Ramezani and co-workers [4] pointed out that abiotic degradation of imidazolinone herbicides is likely to be slow in the environment. It is known [1-3] that different soils contain different fungi, bacteria and actinomycetes, which have been described to be the key factor for the bio-degradation of herbicides in soil. Here, the enantioselective degradation of imazethapyr in Setaria field soil may have also been caused by similar principles.

\section{Conclusion}

A sensitive, rapid and reliable $\mathrm{CE}$ method was applied to the separation of imazethapyr enantiomers using HP- $\beta$ $\mathrm{CD}$ as the chiral selector. The fact that imazethapyr-I was observed to degrade more rapidly under the soil conditions studied, led to the conclusion that enantioselective degradation was present.

\section{References}

1. Lewis DL, Garrison AW, Wommack KE, Whittemore A, Steudler P, Melillo J (1999) Nature 401:898-901. doi:10.1038/44801

2. Buerge IJ, Poiger T, Muller MD, Buser HR (2006) Environ Sci Technol 40:54435450. doi:10.1021/es060817d

3. Yi F, Guo BY, Li HF, Marriott P, Lin JM (2007) Electrophoresis 28:2710-2716. doi: 10.1002/elps.200600705

4. Ramezani M, Oliver DP, Kookana RS, Gill G, Preston C (2008) J Environ Sci Health B 43:105-112

5. Peoples TR, Wang T, Fine RR, Orwick PL (1985) Br Crop Prot Conf Weeds 1:99-106

6. Wang Z, Ouyang J, Baeyens WRG (2008) J Chromatogr B Analyt Technol Biomed Life Sci 862:1-14. doi:10.1016/j.jchromb. 2007.11 .034 